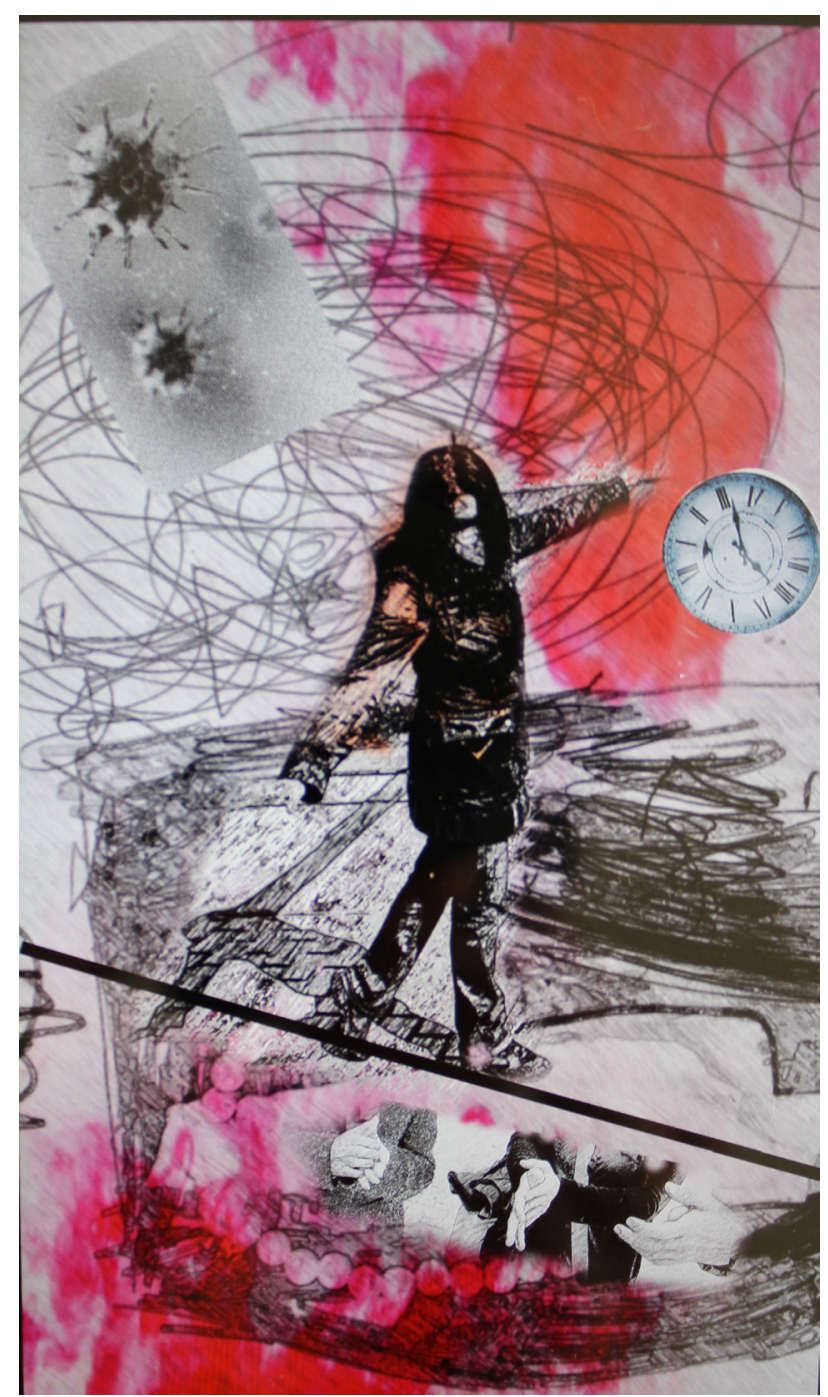

\title{
En la Cuerda Floja
}

\section{Técnica}

Dibujo e infografía.

\section{Reflexión}

Me sentí en un espacio atemporal, en un intento constante de estar presente, en equilibrio, mientras armonizaba tareas y afectos, como una funambulista, en la cuerda floja, en las salidas furtivas al supermercado, en el miedo de miradas a distancia, en las noticias diarias a escondidas para que mi hija no se alarmara, ocultando sonrisas perdidas por la casa entre ecos de aplausos y caceroladas.

\section{Autora}

María Dolores López Martínez. I Máster de Arteterapia y Mediación Plástica. Universidad de Murcia. (2005/2007). Docente en el Departamento de Expresión Plástica, Musical y Dinámica.

Arteterapia: papeles de arteterapia y educación artística para la integración social. Monográfico: Las miradas del arte y el arteterapia en tiempos de la Covid19. ISSN-e: 1988-8309 https://dx.doi.org/10.5209/arte.75920 